\title{
Doing Orthodox Political Theology Today Insights from the Document For the Life of the World: Toward a Social Ethos of the Orthodox Church (2020)
}

\author{
Nikolaos Asproulis
}

The document titled For the Life of the World: Toward a Social Ethos of the Orthodox Church, authored by a special commission of Orthodox scholars appointed by the Ecumenical Patriarch Bartholomew is a document that can be definitely understood as a political manifesto of Eastern Orthodoxy for the 21 $1^{\text {st }}$ century, namely for this period of history and not for a by-gone historical setting or a Christian utopia (either the Byzantine Empire or Holy Russia), a period of time with urgent problems and challenges that call for our attention. Therefore, bringing to the fore the personalist anthropological view inherent in the document itself, an attempt has been made in the text to critically reflect and highlight certain relevant aspects of the document (a positive reception of liberal democracy, human rights language, solidarity to the poor, etc.). The goal is to show how theologically important this document is for the Church witness to our pluralistic world.

Keywords: Political theology, imago Dei, human dignity, Church and World Dogmatics, liberal democracy, human rights, solidarity

\section{Introductory remarks: A note on political theology}

Due to its strong liturgical vision, the Orthodox Church often expresses an ambiguity towards the engagement with historical and social affairs, largely focusing instead on the transfiguration of the present aeon through the inspiration of the Holy Spirit. Indeed, it was widely considered that Orthodox theology was "antipolitical" in nature, ${ }^{1}$ having nothing to do at all with the

\footnotetext{
* Dr. Nikolaos Asproulis, deputy director, Volos Academy for Theological Studies, Lecturer, Hellenic Open University, Kriton str. 16, Athens, Greece 11744, asprou@acadimia.org; florovskian@gmail.com.

${ }^{1}$ In his autobiographical interview, Fr. Georges Florovsky, the eminent Russian émigré Orthodox theologian of the $20^{\text {th }}$ century has stated (in an indirect opposition to the political involvement of his counterparts of the Russian Religious Renaissance") that "I am an antipolitical being: politics is something I do not like. It does not mean I ignore the existence of politics, I know it does [exist], but I have not the slightest desire to be involved." Although without reservations and nuances, this came to be the predominant example followed by the Church and theology with regards to earthly affairs during the last century. See: Andrew Blane and Thomas Bird, "Interview with Fr. Georges Florovsky, April 5, 1969," 43 : (unpublished typescript) as cited in Paul Gavrilyuk, Georges Florovsky and Russian Religious Renaissance (Oxford: Oxford University Press, 2014), 72.
}

RES 13 (1/2021), p. 16-30

DOI: $10.2478 /$ ress-2021-0002 
problems of actual life. In contrast, such a strong political attitude was explicitly attributed to Western theology, as a result of the profound historical commitment which has characterized its various currents since early times. At the same time, however, since our Lord Jesus Christ assumed the fullness of human nature, this means that the Church too has to assume every aspect of human life (social, political, existential needs, etc.) as well as the entire cosmos, towards its fulfillment, namely its transformation to a "New Creation" in the Kingdom. This fundamental theological assumption led some important $20^{\text {th }}$-century Western theologians (i.e. J.B. Metz, J. Moltmann, D. Solle, G. Gutierrez, L. Boff, etc.) to work and develop various forms of a political theology (i.e. liberation theologies, theology of hope, etc.) which would take seriously into account the political dimension of public life, bringing Christianity into a timely and creative dialogue with the challenges posed by post-modernity.

Eastern Orthodoxy, due mainly, but not exclusively, to historical reasons, reluctantly or suspiciously encountered this opening of the Western theologies to the modern challenges. As a result, this hesitancy rendered itself incapable of developing a comprehensive political theology. That being said, one should not fail to point also to certain elements of political thought that one can trace within the patristic tradition from the early period up to the medieval times or certain contemporary voices, who undertook the lead, following the example of the great Church Fathers, to dialogue with the world: not by rejecting the liturgical/Eucharistic nature of the Church, but by robustly elaborating a theology of life and ethos relevant for the needs of the world today.

This hesitancy to tackle these sorts of issues seems to have changed somewhat during the last decade. The year 2012 was a landmark year for $21^{\text {st }}$ century Orthodox theology, although one can certainly refer to certain endeavors having taken place in the context of émigré religious philosophy in the first decades of the last century or the so-called "theology of the 60s" in Greece which followed, more or less, the innovative breeze of Russian theology in the diaspora. Figures like Vladimir Solovyov, Sergii Bulgakov, Elizabeth Behr-Sigel, and others to name only a few and perhaps the most eminent, can give us a brief history of the involvement of modern Orthodox theology in political and social affairs. ${ }^{2}$ In this vein, two quite promising studies

\footnotetext{
${ }^{2}$ See: Michael Plekon, "Eastern Orthodox Thought," in The Blackwell Companion to Political Theology, eds. Peter Scott and William T. Cavanaugh (Blackwell Publishing, 2004), 93106; Nathaniel Wood and Aristotle Papanikolaou, "Orthodox Christianity and Political Theology: Thinking Beyond Empire," in T\&T Clark Handbook of Political Theology, ed. Ruben Rosario Rodrigeuz (London: T\&T Clark, 2020), 337-51; Kristina Stoeckl, Ingeborg Gabriel and Papanikolaou, eds., Political Theologies in Orthodox Christianity: Common
} 
Nikolaos Asproulis

have been authored by Aristotle Papanikolaou and Pantelis Kalaitzidis, ${ }^{3}$ both destined to become perhaps the first systematic attempts by far towards a necessary paradigm shift in Orthodox theology.

But what was the goal of such a political theology ${ }^{4}$ in the first place? Even though one can find today many studies dealing with diverse aspects and currents of political theology in the major Christian traditions, ${ }^{5}$ ranging from the biblical narrative (i.e. the case of Jesus himself or St. Paul) ${ }^{6}$ through patristic and medieval theology to the present time, the term seems to have been used first by Carl Schmitt in his book of the same title in $1922 .^{7}$ During the first half of the $20^{\text {th }}$ century, the encounter of Christianity with the emerging Marxist and nationalist ideologies led Christian theologians of mainly Western traditions to examine the way theology could conceptualize the political dimension of our earthly existence. Moving beyond this preliminary attempt of Schmitt to formulate such a political theology, this concept has been closely linked to the well-known Roman Catholic theologian Johann Baptist Metz, who presented the basic axes of his theological proposal in the 1960s. According to him, the goal of political theology is to render Christian discourse socially relevant. ${ }^{8}$ One should be cautious here to avoid any idealization of a specific version of political ideology (left-wing or right-wing) or any submission to a particular political (left or right) agenda, but mainly as an enterprise to address, from the perspective of the Gospel, the current social and political challenges in a creative, socially-oriented, and effective way. This new perception of theology came to its climax in eminent

Challenges-Divergent Positions (London: T\&T Clark, 2017); Paul Ladouceur, Modern Orthodox Theology: Behold I Make All Things New (London: T\&T Clark, 2019), ch. 14.

${ }^{3}$ Pantelis Kalaitzidis, Orthodoxy and Political Theology (Geneva: WCC Publications, 2012); Papanikolaou, The Mystical as Political. Democracy and (Non) Radical Orthodoxy (Indiana: Notre Dame University Press, 2012). For a critical comparison see: Nikolaos Asproulis, "Pneumatology and Politics: The Role of the Holy Spirit in the articulation of an Orthodox political theology," Review of Ecumenical Studies 7, no. 2 (August 2015): 184-97.

${ }^{4}$ For an overview of the different trends and perspectives of political theology, see: William Cavanaugh and Peter M. Scott, eds., Wiley Blackwell Companion to Political Theology (WilleyBlackwell, 2019).

${ }^{5}$ See: Scott and Cavanaugh, The Blackwell Companion to Political Theology; Rodrigeuz, T\&T Clark Handbook of Political Theology; Elizabeth Phillips, Political theology. A Guide for the Perplexed (Bloomsbury, 2012); William Cavanaugh et al., eds., An Eerdmans Reader in Contemporary Political theology (Eerdmans, 2012).

${ }^{6}$ See for instance: Jacob Taubes, The Political Theology of Paul (Redwood City, 2003); John Howard Yoder, The Politics of Jesus (Grand Rapids, 1994).

${ }^{7}$ Carl Schmitt, Political Theology: Four Chapters on the Concept of Sovereignty, trans. G. Schwab (Cambridge, 1985), (1 ${ }^{\text {st }}$ German edition, 1922).

${ }^{8}$ For these developments in the varied Western currents see: Rosino Gibellini, La teologia del XX secolo (Brescia, ${ }^{4} 1999$ ), especially chapters 9, 10, 12. 
theologians such as Jürgen Moltmann, the Liberation theologians of Latin America and others.

Political theology then focuses on the public dimension of theology, in a way that promotes and cultivates a new way of being based on freedom from any authoritarian condition and love as solidarity to the other, and on the active engagement that overcomes the metaphysical speculation which ignores history and mainly the social and political factors that forge human life. In short, one could define political theology as a new attempt put forth by various Christian theologians to address the challenges and the problems of (post) modernity, a sort of contextual reading and interpretation of tradition in light of the existential and current needs of humanity, as exemplified in the language of human rights, the relationship between Church and state, and so on.

\section{Orthodox political theology: A case study}

The document titled For the Life of the World: Toward a Social Ethos of the Orthodox Church, ${ }^{9}$ authored by a special commission of Orthodox scholars appointed by the Ecumenical Patriarch Bartholomew and blessed for publication by the Holy and Sacred Synod of the Ecumenical Patriarchate, could not but perfectly fit this sort of theology. It is a document which was partially prompted by the Holy and Great Council of the Orthodox Church held in 2016 (cf. Background); a document which can definitely be understood as a political manifesto of Eastern Orthodoxy for the $21^{\text {st }}$ century, this period of the history of salvation, namely post-modernity and not for a by-gone historical setting or a Christian utopia (either the Byzantine Empire or Holy Russia), a period with timely problems and challenges that call for our attention.

It is not an ideologically biased text which aspires to justify or support a specific ideology (of left or right inclination). On the contrary, it is a document that emerged from the deepest inspirations and needs of our present world. Based on the "fundamentally doxological in nature and essentially Eucharistic in character ... service to God" (1), the document points to the fact that "human beings are ... called into loving communion with their neighbors and the whole cosmos" (2). This is exactly the goal of the document: to serve the world in its entirety, to serve humanity, so as to inspire a new ethos on the way to the Kingdom.

\footnotetext{
${ }^{9}$ https://www.goarch.org/el/social-ethos?p_p_id=56_INSTANCE_km0Xa4sy69OV \& p_ p_lifecycle=0\&p_p_state $=$ normal \&p_p_mode $=$ view $\&$ p_p_col_id $=$ column $-1 \&$ p_p_col_ count=1\&_56_INSTANCE_km0Xa4sy69OV_languageId=en_US (last accessed March 1, 2021). All the references to the paragraphs of the document are put at the end of the quotations in parenthesis. For a recent positive evaluation of the document see: Vasileios Makrides, "Le nouveau document social de l'Église orthodoxe: son orientation, son élaboration, son contexte et son importance," Istina 65, no. 4 (2020): 387-414.
} 
Nikolaos Asproulis

In the remainder of this paper, an attempt is made to critically reflect and highlight certain relevant aspects of the document closely linked with our present-day setting. It is not our intention to discuss the whole variety of topics. Our goal is to show how theologically important this document is for the Church witness to our pluralistic and not to some other world. Before, however, diving into the text itself, a special explanation of the method through which the document is interpreted is a necessary requirement.

\section{A methodological note}

Although it is widely recognised that modern Orthodox theology has finally overcome the so-called "Babylonian or scholastic captivity" (namely the use of alien, principally Western/scholastic methods of doing theology, during a period of 500 years after the fall of Byzantium), it seems to have fallen prey to a new form of captivity, which I would call a "pre-modern captivity." This means that a special reception of the patristic tradition as normative, outside of which no theology is possible in an Orthodox manner, continues to occupy a more or less triumphalist place, often becoming an insurmountable obstacle in its encounter with modernity and late modernity. This way of doing theology determines its method, content, as well as its character.

If this is still more or less the case, a distinction is needed between "Church Dogmatics" and "Church and World Dogmatics" - proposed by Paul Valliere in his important work titled Modern Russian Theology: Bucharev, Soloviev, Bulgakov, Orthodox Theology in a New Key, ${ }^{10}$ in order to describe the two major theological currents in the recent history of modern Orthodox theology: "neo-patristic synthesis" (exemplified especially by Georges Florovsky, Vladimir Lossky, John Meyendorff, Alexander Schmemann, John Zizioulas, etc.) and the "Russian Religious Renaissance" (including Vladimir Soloviev, Sergii Bulgakov, Pavel Florenski, etc.). This two-fold typology can be useful here as the methodological standpoint through which one should read the document under discussion. But how might these two models of theology be understood? ${ }^{11}$

The concept of "Church Dogmatics" on the one hand primarily relates to a theology proper, in other words, to a theology ad intra, in terms of a

\footnotetext{
${ }^{10}$ Paul Valliere, Modern Russian Theology: Bucharev, Soloviev, Bulgakov, Orthodox Theology in a New Key (Edinburg: T\&T Clark, 2000), 306-9.

${ }^{11}$ I draw here on my previous discussion of this typology: "Is a dialogue between Orthodox theology and (post) modernity possible? The case of the Russian and Neopatristic «Schools»," Communio 54, no. 2 (2012): 203-22; idem, "“Church and World Dogmatics». The ecumenical need of a paradigm - shift in the modern orthodox theology and education," in: Review of Ecumenical Studies 5, no. 2 (2013): 154-61.
} 
classic doctrinal theology. "Church and World Dogmatics" on the other, intends to formulate open-ended theological hermeneutics by which theology being based on firm doctrinal assumptions aims at addressing the challenges posed by (post)modernity. This is a sort of systematic theology, a theology ad extra in constant dialogue with the various intellectual currents. It is clear then that the way Orthodox theology is being currently performed, follows the first type, that of Church Dogmatics. In order, however, to open itself to the wider world, as the latter is experienced in the actual life of the people, theology needs to embrace the second type of doing theology, that of "Church and World Dogmatics." It is to this second type of doing theology, that the present document clearly fits, since,

we are called, ... not to accommodate ourselves to the practical exigencies of the world as we find it, but instead ever and again to strive against evil, however invincible it may at times appear, and to work for the love and justice that God requires of his creatures, however impractical that may at times prove" and this is so because "The Church knows that such efforts are never in vain, moreover, because the Holy Spirit is also at work in all the labors of the faithful, bringing all things to their fruition in due season (Romans 8:28) (4).

It is exactly this openness to the world, the creation of God that is stressed throughout the document. It is the need of the Church and its theology to embrace or rather to bring to the fore this dialogical ethos in its loving and soteriological encounter with history and cosmos. Without this dialogue, the mission of the Church remains unfulfilled. Therefore, the "Church and World Dogmatics" type of theology does not simply attempt to define or redefine the doctrine of the Church in a modern tongue. It essentially intends to show the soteriological relevance of this doctrine "for the life of the world," insofar as this "is humanity's vocation not merely to accept - but rather to bless, elevate, and transfigure - this world, so that its intrinsic goodness may be revealed even amidst its fallenness" (4). It is a theology that begins with the Church but does not stop to the Church; it rather speaks to the world, it opens its vision to the cosmos in order to meet both the individual creatures and creation in its entirety with the aim to transform the world, to offer a foretaste of the coming Kingdom. This way of theologizing expressed in the document does not reflect a linear process towards the eschata, but a dialectic which takes seriously into account the presence of "evil" in this fallen order, which by no means considers it as the "condition God wishes for his creation" (4). This dialectic between history and eschata, a central cornerstone of Christian existence, is precisely witness to this liberating ethos of the Church, which the present document aspires to briefly describe. 
Nikolaos Asproulis

\section{Sources and foundations}

Looking through the document, one gets a clear idea of the sources employed in the development of its argument. Full of Biblical (both Old and New Testament, this shows the priority given to regula fidei, the apostolic tradition, not always evident in Orthodox documents: cf. par. 8, 16, 32, 39 with a special focus on the Old Testament, etc.), patristic and liturgical references (mainly from the period of the undivided Church and only the necessary: par. 29, 38, etc.), but also synodical definitions (Ecumenical Councils, cf. 31) and contemporary theologians (Maria Skobtsova, Metropolitan John Zizioulas, etc.), the document is firmly grounded in the tradition, yet avoiding the impasse of a theology of repetition, which still seems to occupy a central place in academic Orthodox theology.

Already in the introduction, the document indirectly refers to certain conditions upon which the Orthodox ethos should be grounded. Based on a firm biblical and patristic account the authors allude to the human person, who, being created in the image and likeness of God (Gen. 1:26), is called upon to reflect the "dialogical reciprocity," 12 in other words a perichoretic model of life, the loving communion, existing in the very being of God himself. This is not an abstract reflection, but the Christian life experienced in the Eucharist, a profound incarnational vision, albeit not always clearly manifested in the historical journey of Christian communities, which are wavering between "desert and empire." ${ }^{13}$ A theology of personhood is implied here (not fully articulated yet) where the otherness and dignity of each human is boldly affirmed. As the document puts it,

It was a community established in the knowledge that in Christ there is neither Jew nor Greek, neither slave nor free, nor any division in dignity between man and woman, because all are one (Galatians 3:28)' (6). 'And as we are made to be in communion with God in Jesus Christ, Irenaeus of Lyons writes that the human being was made in 'image of Christ' (1).' That being said, 'the surest warrant for and charter of an Orthodox social ethos is found, before all else, in the teachings of Christ (6).

It is the person of Christ, his historical presence and teachings, which became the model after which every human has been ultimately created. It is indeed, a strong claim which highlights the bold Christological backbone of

\footnotetext{
${ }^{12}$ For the term, I draw on Nikolaos Loudovikos' A Eucharistic Ontology: Maximus the Confessor's Eschatological Ontology of Being as Dialogical Reciprocity (Brookline, MA: Holy Cross Orthodox Press, 2010).

${ }^{13}$ See: Florovsky, "Antinomies of Christian History: Empire and Desert," in idem, Christianity and Culture, Collected Works, vol. 2 (Nordland-Belmont, Mass., 1974), 67-100.
} 
a Christian theology (Orthodox included). This means that the Orthodox social ethos can by no means be understood as a mere theory. It is rather a deeply incarnational ethos, embedded in a concrete (historical and not ideal) community, "the local Church committed to a radical life of love, in which all other allegiances - nation, race, class - were replaced by a singular fidelity to Christ's law of charity" (6).

The strong Pauline claim to the Galatians points to the uncontested dignity of human, which "being made in the image and likeness of God," modeled in this respect after its archetype of the loving communion of the Trinitarian persons, becomes a clear indication of the Church's high anthropological vision of humanity which has been called to a "loving communion with their neighbors and the whole cosmos" (3). In spite of the various forms of evil evident in the present eon, the Church "enjoys a special knowledge of the love of God as revealed in the person of Christ" (7). This by no means diminishes the fact that "the deepest moral commandments of God's law are inscribed upon every human heart" (7), meaning that all people somehow share in the (common) "good" (7) (a clear indication to the "Church and world Dogmatics" theological method). This is a profound reference to the deep (i.e. ontological) interdependence of all the people and the entire cosmos. By alluding again to a patristic authority, such as Maximus the Confessor $\left(7^{\text {th }}\right.$ c.) and his doctrine on the Logos-logoi (7) the document points to the "prophetic" role (and not to any special privilege based on national, or racial foundations) of Christians in this world that is to their responsibility and commitment to the salvation of all creation. It is then not a document that tries to impose a superficial (ethical or other) doctrine upon the people of God or even the entire cosmos. It rather appeals to the bold Christological ethos which accounts for the cooperation between God and human, in its struggle against evil on the way towards the Kingdom. What may be lacking in this anthropological view, is a more open and inclusive understanding of the human identity in terms of "divinanimality," ${ }^{14}$ which takes seriously into account the role animals can play in the definition of the imago Dei in human as well as theirs (animal) role in the salvation of the entire cosmos. In an age where animal suffering and abuse is widely recognized as a problem relating not only to our pet culture but more importantly to our production models, a cautious criticism of any human exceptionalism would perfectly fit the divine plan of salvation for the whole creation.

\footnotetext{
${ }^{14}$ Stephen Moore, ed., Divinanimality: Animal Theory, Creaturely Theology (New York: Fordham University Press, 2014).
} 
Nikolaos Asproulis

\section{Political-social affairs and the Orthodox Church in the age of (post) modernity}

In the first major section of the text titled "the Church in the public sphere," the document, surprisingly for a traditional audience but also in a frank manner criticizes "a dangerous temptation among Orthodox Christians to surrender to a debilitating and in many respects fantastical nostalgia for some long-vanished golden era," the glorious Byzantine, Russian, etc. imperial past, which revolves around certain pre-modern, unfree and authoritarian forms of government and organization of life. In contrast and in line with the major achievements of modern societies, the document represents a positive attitude towards liberal democracy, not always the case with Christian (Orthodox included) thinkers. ${ }^{15}$ As it is stated:

civil order, freedom, human rights, and democracy are realities in which citizens may trust; and, to a very real degree, these societies accord persons the fundamental dignity of the liberty to seek and pursue the good ends they desire for themselves, their families, and their communities (10).

Again, the goal is not to sanctify any earthly order itself (meaning to replace a past ideal polity with a present one), a culture or any specific holy nation, but to support forms of government and social organization which clearly respect as their sine qua non condition the image of God in every human person. Moreover, even cultural, religious and social pluralism, a prevailing reality in today's (western) societies (as a result of immigration but also of the globalization process), which sometimes provokes negative reactions from the side of the traditional Orthodox countries, should be regarded as a blessing of God, which seeks to further substantiate the deep ontological link between people and cultures (12). This temptation of exclusivism, and nationalism ${ }^{16}$ ("There can be no such thing as a "Christian nationalism," or even any form of nationalism tolerable to Christian conscience”, 11), any coalition with authoritarian earthly regimes appears to be the most serious threat which still challenges the unity as well as the very witness of Orthodoxy to the world.

The Orthodox Church has allowed for the conflation of national, ethnic, and religious identity, to the point that the external forms

\footnotetext{
${ }^{15}$ See the discussion in: Papanikolaou, The Mystical as Political.

${ }^{16}$ For an overall critical discussion of the relationship between Orthodoxy and nationalism see the double issue of St. Vladimir's Theological Quarterly, 3-4 (2013) which contains the proceedings of an international conference held in Volos in 2012 (May 24-27) on the topic: "Ecclesiology and Nationalism in the Postmodern Era."
} 
and language of the faith - quite evacuated of their true content - have come to be used as instruments for advancing national and cultural interests under the guise of Christian adherence. And this has often inhibited the Church in its vocation to proclaim the Gospel to all peoples (10).

Unless the Church overcomes (or rather transforms) the various natural ties, such as nation, race, gender, language, culture, etc., its mission to evangelize the entire world is clearly subject to the threat of exclusivism that challenges the catholicity of Christian existence, the ecumenical character of salvation, leading to its particularization and marginalization.

Another important political aspect of this section that should be clearly considered is the positive reception of secularism. It is not the place here to discuss in detail this complex topic. If one would like to summarize the discussion, it needs to refer to the existing consensus among contemporary sociologists of religion that secularization is a more nuanced and complex phenomenon that varies widely depending on the specific context. It has been justly argued that the religious and the secular are "inextricably bound and mutually conditioned." ${ }^{17}$ By saying this, one is obliged to talk about multiple secularizations or patterns of secularization, following the most recent analysis in this vein that accounts for "multiple modernities." ${ }^{18}$ Regardless of this general agreement, certain features have already been determined by which an attempt has been made by sociologists and political theorists to describe or evaluate this phenomenon: a) Structural differentiation of the secular sphere; b) decline of religious belief and, c) privatization of religion. ${ }^{19}$

That being said, the document seeks to go beyond any naïve reduction of the discussion to a degradation or privatization of religion in secular societies, or any justification of a separation wall between Church and state. In contrast, it highlights the need of the Church to free itself from the various forms of a "slavish and unholy submission to earthly power and a complicity in its evils...so that it may more faithfully conduct and promote her mission to all nations and persons" (13). After all, this is its mission, the salvation of the whole cosmos, according to the Gospels, not the assumption of political power or submission to any kind of earthly power. This equates to a devi-

\footnotetext{
${ }^{17}$ Jose Casanova, "Rethinking Secularization: A Global Comparative Perspective," The Hedgehog Review 8, (Spring \& Summer 2006): 7-22, here at 10 and passim.

${ }^{18}$ This term was initially coined by S. N. Eisenstadt, "Multiple Modernities," Daedalus 129, no. 1 (Winter 2000): 1-29.

${ }^{19}$ In this perspective see: Casanova, "Rethinking Secularization," 7ff; idem "The Secular, Secularizations, Secularisms," in Rethinking Secularism, eds. Craig Calhoun, Mark Juergensmeyer and Jonathan VanAntwerpen (Oxford: Oxford University Press, 2011), 60ff.
} 
Nikolaos Asproulis

ation of the Church's main goal which is the transfiguration of the world, since how can one transfigure the world if one has been fully identified with it? The fundamental dialectic between history and eschata lies again in the background of the discussion of the relationship between Church and state. This dialectic, however, does not reject the cautious cooperation of the Church with institutions and governments in supporting and helping the needy people and the marginalized. As it is stated:

In no sense does this preclude the Church from direct and robust cooperation with political and civil authorities and organs of state in advancing the common good and pursuing works of charity (14).

The Church is not of this world, but apparently inhabits this world (John $18,36)$. Again the incarnational model submitted by the Jesus history is clearly put forth here, so as to secure that the Church should continuously assume, that is stand by, all those in need its help: "Even then, in times of distress, such as periods of plague or famine, Christians often distinguished themselves by the selflessness of their service to their neighbors" (14). ${ }^{20}$ The secular idea of the "common good" comes to the fore here as the ground upon which the Church and any secular state can cooperate. The Church needs to "work with governments toward the common good and to struggle against injustice" (14). This commitment goes beyond an institutional exclusivism which understands the Church as an association of people already saved. It alludes to an understanding of the Church as an open community, which on its way to the kingdom, commits itself to the "common good" as the minimal ground of understanding between itself and the earthly powers in favor of those that live in the margins. Christ himself became flesh and human not to become one of the rulers of this aeon, but basically to reverse or rather annul the hierarchy of this world, offering his Kingdom to all those that have been degraded or diminished by the powerful this world.

The innate incarnational foundation of the social ethos provided in the present document is further evidenced in the section titled: "Poverty, Wealth, and Civil Justice." ${ }^{21}$

When the eternal Son became human, divesting himself of his divine glory and exchanging the 'form of God' for the 'form of a servant' (Philippians 2:6-7), he elected thereby to identify himself

\footnotetext{
${ }^{20}$ Observe the provision here of the Covid-19 pandemic which outbroke almost immediately after the launch of the document.

${ }^{21}$ For a general recent overview of the relation between Orthodoxy and social issues and science see: Makrides, "Orthodox Christianity and Social Science: Overcoming Older Complications and Attempting a Productive Interaction," Journal of Eastern Christian Studies 69, no. 1-4 (2017): 137-64.
} 
with the most marginal, politically powerless, and socially disadvantaged persons of his age (32).

The ethos described here, with a clear Christological connotation, is deeply embedded in our everyday Christian existence. In other words, it by no means can be viewed as an abstract social theory or banal ideology. Being created in the image of God that is in the image of Christ, humans are called to make Him present in this world through their solidarity with the poor and everyone in need. If "life in Christ [is understood] as one of radical solidarity," both the Church and individual Christians should follow the long tradition of the Church Fathers (St. Basil, St. John Chrysostom, etc.) who strongly criticized the unjust conditions and practices against the poor people (33). Any sort of exploitation of the poor and the marginalized people by those who seek their own profit in the present context of our neo-liberal and market economies should be condemned by an ethos that is based on a Christ-like perception of human being which conceives of the human being as an irreducible, unique entity, despite its own financial or social condition. A personalist anthropological view is again at play here, where communion and otherness as its basic cornerstones, express the foundational conviction of Christian faith that every human being is not only an image of God, but one could say, an image of the poor, of the neighbor, to the degree that (according again to the patristic tradition), "human beings are social and political creatures by nature, who must share their goods with one another in order to end poverty" (34). The Church as a body needs to "obey these scriptural and patristic teachings" (34) so as to follow the commandments of its Lord, otherwise, there is always the temptation to be transformed by a power of this aeon which further contributes to the devaluation of the human dignity and the marginalization of the poor. Unless the social ethos is an incarnational one relevant to concrete persons and not abstract ideas, the Church's teachings and doctrines become mere ideological propositions, subject to depreciation or rejection altogether.

Most of all, along with St Basil, and St Ambrose, and other of the Fathers, the Orthodox Church must insist upon the responsibility of society to provide a social safety net that genuinely protects the poor and disadvantaged from absolute penury, degradation, homelessness, misery, and despair (38).

This is the least that Church communities that follow the steps of their Lord can do. Nowadays the institutional Church shows important work in terms of solidarity to people in need. But is this simply to what the document aspires? Unless the ethos of the Church is inspired by a firm and vital conviction for the irreducible dignity of the human being, no solidarity work 
Nikolaos Asproulis

can really affect the legislation or practices of this world. It is not enough to help the people in need; it is more important to transform the conditions that contribute to such an unjust situation.

The Church must in every generation, remembering the example of the Church of the Apostolic age, ask of every society whether there are not effective means - and perhaps new economic models - by which it would be possible to achieve a more just distribution of wealth, and thereby a more radical commitment to the common good, of society and of the planet we all must share. For St. Maria Skobstova, this is a mandate addressed to everyone seeking to rise from earth to heaven and rejoice with the angels when a cup of water is offered to a single individual in the name of the Lord: 'A person should have a more attentive attitude to his brother's flesh than to his own. Christian love teaches us to give our brother not only material but also spiritual gifts. We must give him our last shirt and our last crust of bread. Here personal charity is as necessary and justified as the broadest social work. In this sense there is no doubt that the Christian is called to social work. He is called to organize a better life for the workers, to provide for the old, to build hospitals, care for children, fight against exploitation, injustice, want, lawlessness' (41).

Another section of the text, worthy to be discussed is the one titled "Orthodoxy and Human Rights." It is not a secret to say that the human rights language is not a language easily acceptable by the Orthodox imagination. Being understood, either as a backbone of western liberal democracy or as a result of the predominant individualism, human rights are often seen as incompatible with the Orthodox communal ethos, which is supposed to give priority to relationships between humans rather than to a self-defined, and self-referent individual, the Ego of modernity. Although such a criticism is not without its merits, to the extent that it presupposes a different ontological view, substantialist $v$ s. personalist ${ }^{22}$ this sort of a clear-cut imagination where personhood opposes the individual appears to be outdated, while it does not take into account the close relationship between the two upon which the human identity is founded. While it is true that personhood is recognized as the most important contribution of Christianity to the history of ideas, one cannot downplay the fact that the human rights language largely draws on our Jewish-Christian tradition, while its major impulse is to affirm and then secure the very dignity of every single human being. In view of the

\footnotetext{
${ }^{22}$ For this see: John D. Zizioulas, Being as Communion (Crestwood: St. Vladimir's Seminary Press, 1985); idem, Communion \& Otherness (London: T\&T Clark, 2006).
} 
dialectic between history and eschata, the human rights language should be thought of as an "in-between" state which will be fulfilled in the eschata, in the Kingdom of God, where the individual will be fully transformed to personhood.

Therefore, the focus of the document on human rights should be read in this light. By referring to "the French Assembly's Déclaration des droits de l'homme et du citoyen (1789) to the United Nations' Universal Declaration of Human Rights (1948) and its sequels" (61), the document shows that, the moral claims of every human being upon his or her society and its laws are more original and more inviolable than the rights of estates or governments or institutions of power. This is an assurance largely inherited from the Jewish and Christian sources of European civilization. Orthodox Christians, then, may and should happily adopt the language of human rights when seeking to promote justice and peace among peoples and nations, and when seeking to defend the weak against the powerful, the oppressed against their oppressors, and the indigent against those who seek to exploit them (61).

It is a language that can be received as the minimum secular equivalent of a personalist anthropological view, which aims at defending any person from abuse or oppression, to safeguard human dignity against the powerful and authoritarian regimes of this world. From this point of view,

The language of human rights may not say all that can and should be said about the profound dignity and glory of creatures fashioned after the image and likeness of God; but it is a language that honors that reality in a way that permits international and interfaith cooperation in the work of civil rights and civil justice, and that therefore says much that should be said (61).

There is no Christian, or Church that follows the steps of the Lord of History which would not sign "the chief philosophical principle animating the conventions of human rights theory is the essential priority of human dignity, freedom, equality, and justice in the social, civil, and legal constitution of any nation" (63). Otherwise, the core biblical and doctrinal conviction about the special status of human as the "image of God" is certainly put in jeopardy.

\section{By way of conclusion}

By no means has the document under discussion claims to be exhaustive or definite.

A document of this sort can address only so many issues and its authors can foresee only so many of the additional concerns that 
Nikolaos Asproulis

might occur to those who receive it. It is offered, therefore, with the caution and the humble acknowledgment that it is in many respects quite inadequate as a comprehensive statement of the social ethos of the Church. In that sense, it is at most an invitation to further and deeper reflection on the parts of the faithful (79).

True, the text deals with a wide range of topics, of which only a few have been discussed here: ranging from children affairs, climate change, disability, ecumenical relations, Marriage to Science, technology, sexual abuse, women and much more. Despite possible shortages, like a certain human exceptionalism, still prevailing in the Orthodox milieu, or a lack of reference to animals as creatures of God which do have a place in heaven, or perhaps an overemphasis on western democracies as the sole context to which the described social ethos could be realized, the document signifies a unique moment in the modern history of the Orthodox Church and theology. Under the leadership of the Ecumenical Patriarch, Bartholomew, the scientific committee which conducted this text, aspired to provide a document which by being based on the firm biblical, patristic and doctrinal tradition, seeks to inspire an ethos that would be able to support the Church witness to the present and not an outdated world, in its struggle against the various forms of evil, while at the same time presenting an alternative way of life, capable of transfiguring the present world on its way to the Kingdom.

An attempt has been made in this study to critically reflect and highlight certain relevant aspects of the document (a positive reception of liberal democracy, human rights language, solidarity to the poor, etc.). Our goal was to show how theologically important this document is for the witness of Orthodoxy to the present pluralistic world. By using a "Church and World Dogmatics" methodology, as has been described above, I tried to sketch a possible way contemporary Orthodox theology should be practiced today if it still wishes to be meaningful for the entire world. 